Check for updates

Cite this: RSC Adv., 2017, 7, 26935

Received 12th April 2017

Accepted 27th April 2017

DOI: $10.1039 / \mathrm{c} 7 \mathrm{ra0} 4146 \mathrm{~b}$

rsc.li/rsc-advances

\title{
Transformation of bioethanol to 1,3-butadiene and other bulk chemicals over the surface of $\mathrm{Mg}-\mathrm{Al}$ catalysts
}

\begin{abstract}
Meixiang Gao, ${ }^{\text {ab }}$ Minhua Zhang ${ }^{\mathrm{ab}}$ and Yonghui Li (iD) *ab
The synthesis of bulk chemicals from bioethanol and analysis of the product distribution over $\mathrm{Mg}-\mathrm{Al}$ catalysts were investigated. Preparation methods of co-precipitation, hydrotalcite-like compounds and impregnation were studied. Catalysts were characterized by X-ray diffraction, nitrogen adsorptiondesorption, scanning electron microscopy, transmission electron microscopy, $\mathrm{NH}_{3}$-temperatureprogrammed desorption ( $\mathrm{NH}_{3}-\mathrm{TPD}$ ), $\mathrm{CO}_{2}$-TPD and Fourier-transform infrared spectroscopy of adsorbed pyridines. Different preparation methods had an impact on the surface structure and chemical nature of the catalysts. Ethylene was obtained mainly on sites of strong acids and strong bases. Sites of moderately strong acids and bases were suitable for 1,3-butadiene (BD) formation. To obtain higher BD selectivity, the ratios of $\mathrm{MgO}$ and $\mathrm{Al}_{2} \mathrm{O}_{3}$ must be examined and modifiers used to adjust the acid-base balance must be adopted in $\mathrm{Mg}-\mathrm{Al}$ catalysts.
\end{abstract}

\section{Introduction}

In recent years, the production of chemical raw materials from biomass has become increasingly in demand with development of the economy. In addition to the use as biofuels, bioethanol produced from renewable resources in large amounts holds considerable promise as a building block for the chemical industry. ${ }^{1}$ The process of "green" and renewable 1,3-butadiene (BD) formation from bioethanol is an example of this approach. In 2012, worldwide consumption of BD was $\approx 10$ million metric tons with incremental growth of $1-2 \%$ per year. ${ }^{2}$ Currently, BD is manufactured in a petroleum-refining process as a byproduct of ethylene production, which is expensive. ${ }^{3}$ Moreover, the world is faced with the challenge of high oil prices, depletion of petroleum reserves and environmental issues (including global warming). Hence, it is crucial to develop alternative processes for $\mathrm{BD}$ as well as ethylene production from non-petroleum, renewable resources such as bioethanol. ${ }^{4-7}$ In particular, the process of bioethanol production from non-food biomass feedstock is used widely. ${ }^{8-10}$

The technology of BD formation from ethanol was developed more than one century ago. Two processes were studied for the synthesis of BD from ethanol: Ostromisslenski ${ }^{11}$ and Lebedev. ${ }^{12}$ Several types of materials were used in these reactions, including single oxides, composite oxides, or metal oxides

${ }^{a}$ Key Laboratory for Green Chemical Technology of Ministry of Education, R\&D Center for Petrochemical Technology, Tianjin University, Tianjin 300072, P R China. E-mail: liyh@tju.edu.cn; Fax: +86-22-27401826; Tel: +86-22-27401826

${ }^{b}$ Collaborative Innovation Center of Chemical Science and Engineering, Tianjin 300072, China supported on molecular sieves or clay. ${ }^{13-19}$ At present, the catalyst systems studied have been mainly $\mathrm{Mg}-\mathrm{Si}, \mathrm{Zr}-\mathrm{Si}$ and $\mathrm{Ta}-\mathrm{Si}$. The promotors are major $\mathrm{Ag}, \mathrm{Cu}, \mathrm{Zn}$ and Hf. However, they still exhibit relatively low catalytic activity. Several studies have reported how the reaction of ethanol conversion to BD works on catalyst surfaces, but the structure-property relationship of these catalysts is controversial. ${ }^{20-23}$ Hence, attempts to improve a novel catalyst system are applicable.

According to recent studies, the dehydrogenation of ethanol occurs mainly on basic sites such as $\mathrm{MgO},{ }^{20-22}$ and several reports have pointed out that the Meerwein-Ponndorf-Verley (MPV) reaction occurs over Mg-Al catalyst. ${ }^{24-27} \mathrm{Hence}$, the $\mathrm{Mg}-\mathrm{Al}$ catalyst system was adopted in the present study to study the product distribution of $\mathrm{BD}$ and other bulk chemicals. The preparation methods of co-precipitation, hydrotalcite-like compounds (HTLcs) and impregnation have been studied. The structures and properties of the catalysts and distribution of products on catalysts using these these preparation methods were analyzed, and could lay foundations for the development and application of highly active catalysts.

\section{Experimental}

\subsection{Catalyst preparation}

Three methods of synthesis were used for Mg-Al catalysts.

(1) Co-precipitation: $25 \%$ ammonia solution was added dropwise to mixed $\mathrm{Mg}\left(\mathrm{NO}_{3}\right)_{2} \cdot 6 \mathrm{H}_{2} \mathrm{O}$ and $\mathrm{Al}\left(\mathrm{NO}_{3}\right)_{3} \cdot 9 \mathrm{H}_{2} \mathrm{O}$ aqueous solutions containing $40 \mathrm{wt} \% \mathrm{MgO}$ at $333 \mathrm{~K}$ under vigorous stirring while maintaining the $\mathrm{pH}$ between 9 and 10 . This operation was repeated until complete precipitation. The precipitate was washed in deionized water several times until 


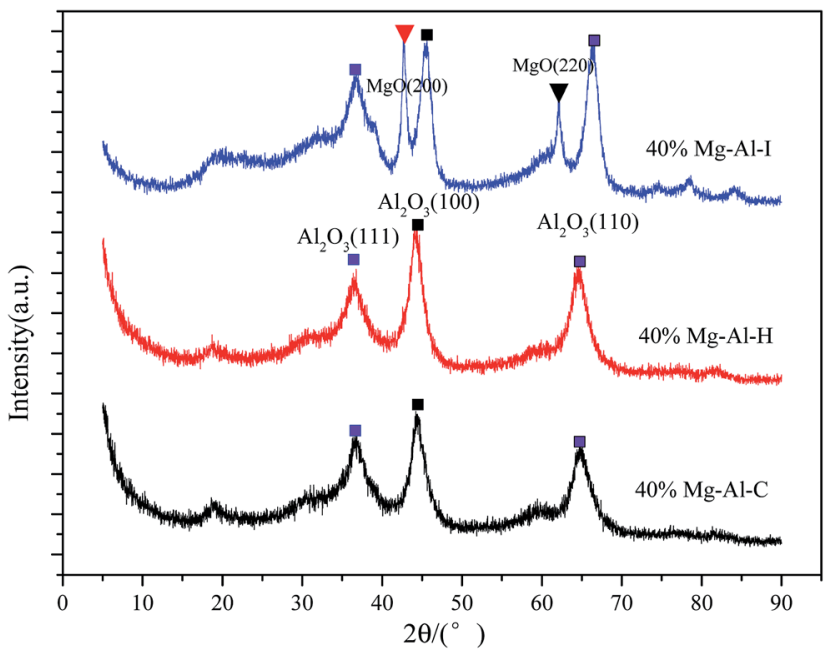

Fig. 1 XRD patterns of $\mathrm{Mg}-\mathrm{Al}$ catalysts using different preparation methods.

Table 1 Structural properties of $\mathrm{Mg}-\mathrm{Al}$ catalysts

\begin{tabular}{lll}
\hline Preparation method & $\begin{array}{l}\text { BET surface area } \\
\left(\mathrm{m}^{2} \mathrm{~g}^{-1}\right)\end{array}$ & $\begin{array}{l}\text { Average pore diameter } \\
(\AA)\end{array}$ \\
\hline Co-precipitation & 166 & 31 \\
HTLcs & 166 & 47 \\
Impregnation & 210 & 62
\end{tabular}

the $\mathrm{pH}$ of the solution was 7 . The product was dried at $353 \mathrm{~K}$ for $6 \mathrm{~h}$ and calcined at $773 \mathrm{~K}$ for $5 \mathrm{~h}$. This sample was labeled as $\mathrm{Mg}-\mathrm{Al}-\mathrm{C}$.

(2) HTLcs: An aqueous solution containing $\mathrm{Mg}\left(\mathrm{NO}_{3}\right)_{2} \cdot 6 \mathrm{H}_{2} \mathrm{O}$ and $\mathrm{Al}\left(\mathrm{NO}_{3}\right)_{3} \cdot 9 \mathrm{H}_{2} \mathrm{O}$ with $40 \mathrm{wt} \% \mathrm{MgO}$ content was added dropwise to another solution $(0.2 \mathrm{~L})$ containing $\mathrm{NaOH}(0.4375$ $\mathrm{mol})$ and $\mathrm{Na}_{2} \mathrm{CO}_{3}(0.1125 \mathrm{~mol})$ in a $0.5 \mathrm{~L}$ beaker under vigorous stirring at $333 \mathrm{~K}$, followed by filtering and washing with boiling distilled water. The precipitate was dried at $353 \mathrm{~K}$ for $6 \mathrm{~h}$ and calcined at $773 \mathrm{~K}$ for $5 \mathrm{~h}$. This sample was labeled as $\mathrm{Mg}-\mathrm{Al}-\mathrm{H}$.

(3) Impregnation: $\mathrm{MgO} / \gamma-\mathrm{Al}_{2} \mathrm{O}_{3}$ catalysts were obtained by incipient wetness impregnation of $\gamma-\mathrm{Al}_{2} \mathrm{O}_{3}$ (BASF) with $\mathrm{Mg}\left(\mathrm{NO}_{3}\right)_{2} \cdot 6 \mathrm{H}_{2} \mathrm{O}$ aqueous solution. After impregnation, the samples were treated under ultrasound for $2 \mathrm{~h}$. Then, the precursors were dried at $353 \mathrm{~K}$ and calcined at $773 \mathrm{~K}$ for $5 \mathrm{~h}$ in a flow of dry air. This sample was labeled as Mg-Al-I.

\subsection{Catalyst characterization}

X-ray powder diffraction (XRD) patterns were obtained by a Multiplex instrument (Rigaku) with a $\mathrm{Cu}-\mathrm{K}$ radiation source operated at $40 \mathrm{kV}$ and $40 \mathrm{~mA}$. Nitrogen adsorption isotherms were measured at $77 \mathrm{~K}$ on a Tristar 3000 volumetric adsorption analyzer (Micromeritics). Before adsorption measurements, all samples were outgassed at $673 \mathrm{~K}$ in a degassing station. Scanning electron microscopy (SEM) images were recorded on a XL30S FEG scanning electron microscope (Philips). Transmission electron microscopy (TEM) images were obtained by a G2 F20
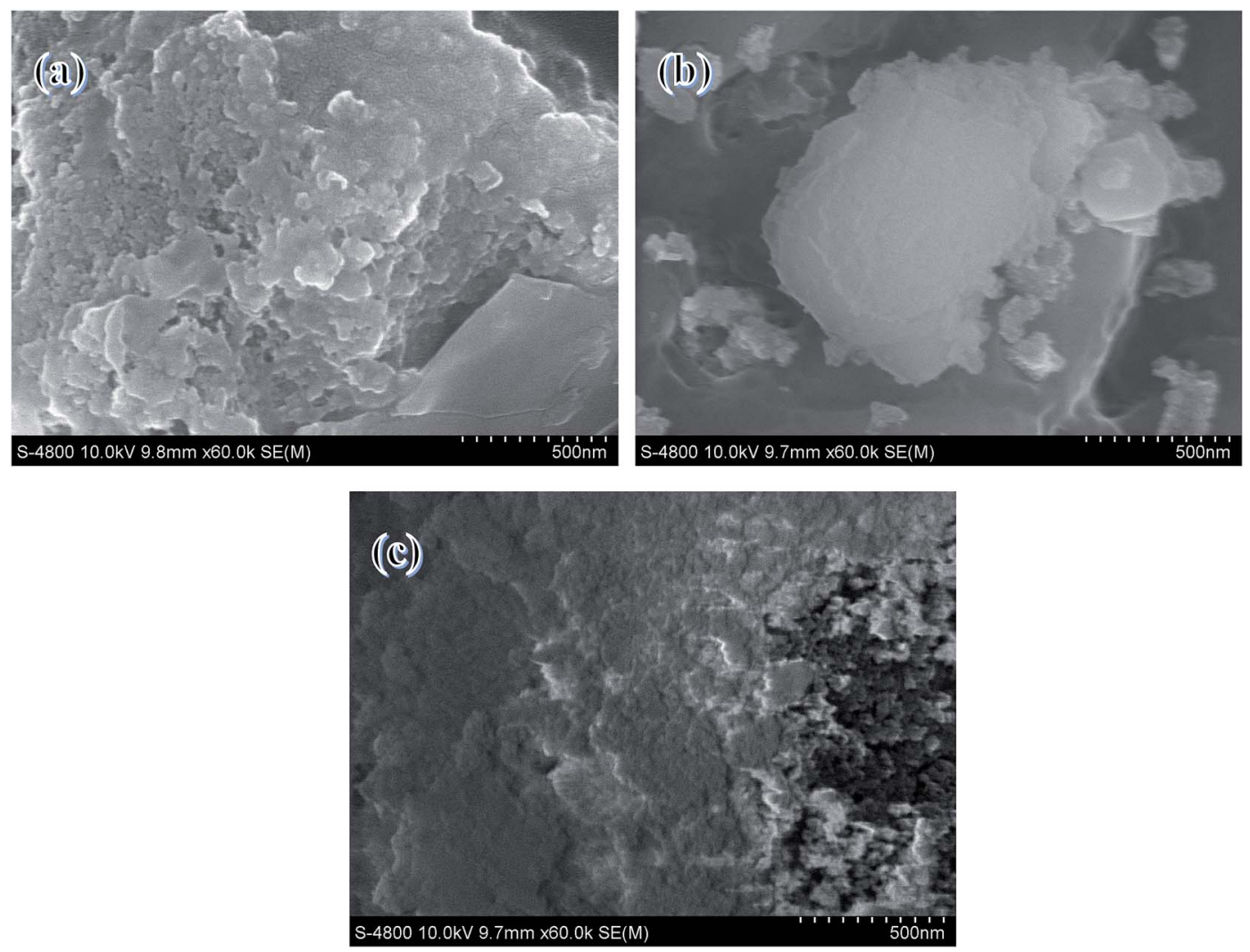

Fig. 2 SEM images of (a) $\mathrm{Mg}-\mathrm{Al}-\mathrm{C}$, (b) $\mathrm{Mg}-\mathrm{Al}-\mathrm{H}$ and (c) $\mathrm{Mg}-\mathrm{Al}-\mathrm{I}$. 
(Tecnai) system operated at $200 \mathrm{kV}$. The nature of acidic sites and basic sites were determined by $\mathrm{NH}_{3}$-temperature programmed desorption (TPD) and $\mathrm{CO}_{2}-\mathrm{TPD}$ recorded through a Autochem II 2920 system (Micromeritics). Adsorbed pyridines were tested on a Nicolet 560 Fourier-transform infrared (FTIR) spectrometer (Thermo Scientific) with 64 scans at $4 \mathrm{~cm}^{-1}$ resolution.

\subsection{Impulse response}

Impulse response experiments were operated on an Auto II 2920 automated catalyst characterization system (Micrometrics) and products were analyzed by an online mass spectrometer (Omnistar MS200; Balzers). The catalyst (100 mg) was fixed in a quartz reactor. Before the experiment, the sample was pretreated in $\mathrm{N}_{2}$ at $773 \mathrm{~K}$ for $2 \mathrm{~h}$ at a heating rate of $20^{\circ} \mathrm{C} \mathrm{min}{ }^{-1}$, and

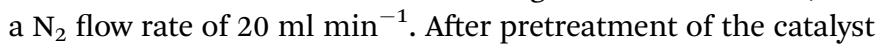
and a temperature drop to $698 \mathrm{~K}$, an ethanol/He gas mixture was injected onto the catalyst surface through a quantitative loop (1 $\mu \mathrm{l})$. Mass spectrometry was used to detect all possible products.

\subsection{Catalytic test}

Ethanol-conversion experiments were performed in a fixed-bed reactor system. The catalyst $(3.0 \mathrm{~g}$; sieved to a particle size of $0.425-0.850 \mathrm{~mm}$ ) was loaded in the middle of the quartz tube. Before the reaction, catalysts were pretreated to the reaction temperature $\left(673 \mathrm{~K}\right.$; heating rate $=5.0 \mathrm{~K} \mathrm{~min}^{-1}$ ) with $\mathrm{N}_{2}$ flow $\left(40 \mathrm{ml} \mathrm{min}^{-1}\right)$ as the carrier gas. The reaction was then performed with a weight hourly space velocity (WHSV) of $1.8 \mathrm{~h}^{-1}$ at $673 \mathrm{~K}$. Products were detected online by an 7890A system (Agilent) equipped with a carbon-plot column $(0.535 \mathrm{~mm}$ (id) $\times 3$ $\mu \mathrm{m}$ (thickness) $\times 30 \mathrm{~m}$ (length)) and thermal conductivity detector (TCD).

\section{Results and discussion}

\subsection{Properties of $\mathbf{M g}-\mathbf{A l}$ catalysts}

XRD patterns of $\mathrm{Mg}-\mathrm{Al}$ catalysts are shown in Fig. 1. XRD patterns of the $\mathrm{Mg}-\mathrm{Al}-\mathrm{C}$ sample showed the typical features of crystalline $\mathrm{Al}_{2} \mathrm{O}_{3}$. For $\mathrm{Al}_{2} \mathrm{O}_{3}$, the peaks at approximately $37^{\circ}$, $45^{\circ}$ and $65^{\circ}$ corresponded to diffraction by planes (111), (100)
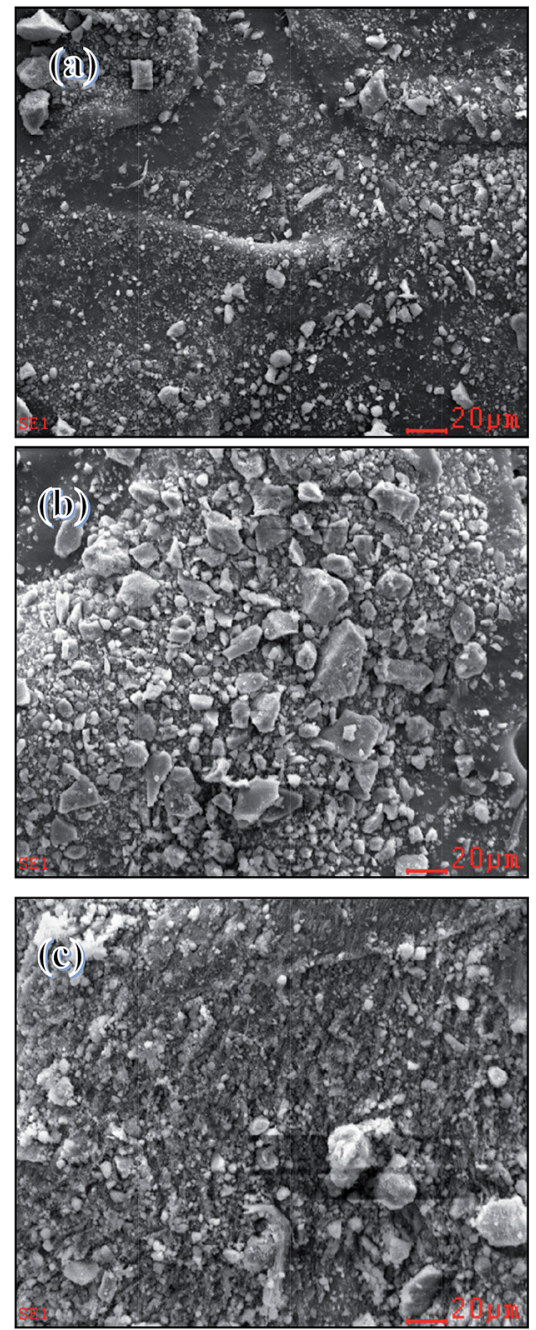
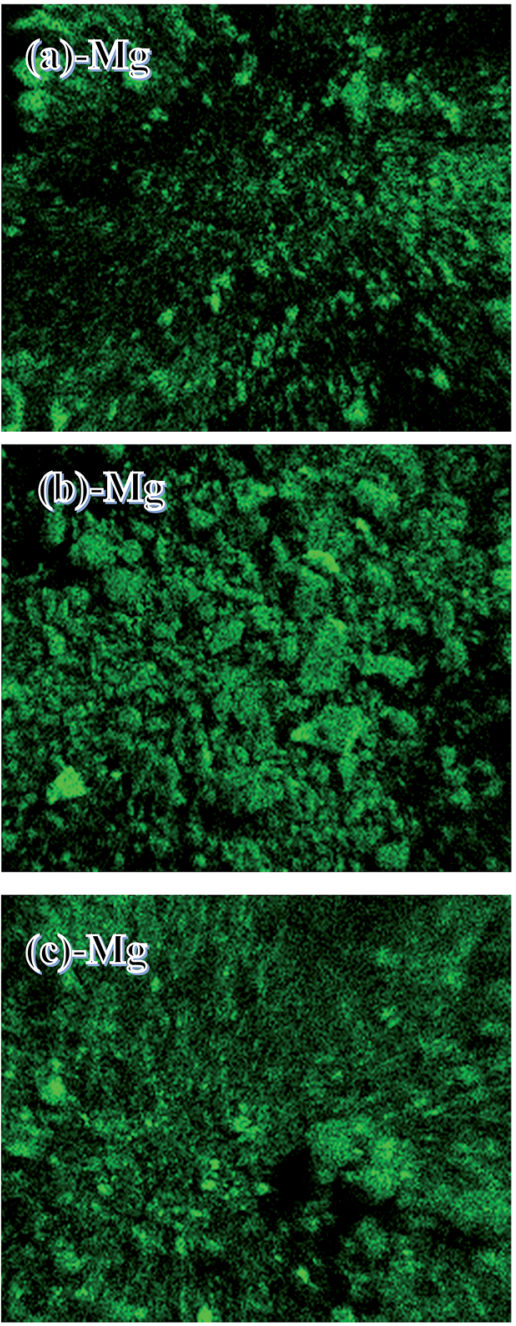
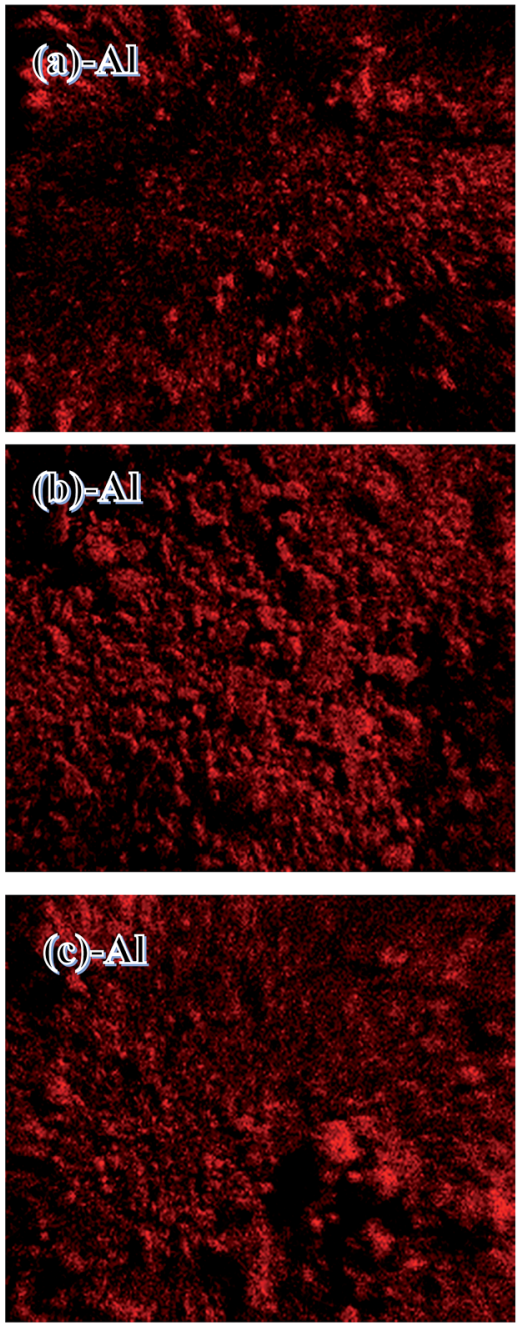

Fig. 3 SEM/EDX measurements of (a) $\mathrm{Mg}-\mathrm{Al}-\mathrm{C}$, (b) $\mathrm{Mg}-\mathrm{Al}-\mathrm{H}$ and (c) $\mathrm{Mg}-\mathrm{Al}-\mathrm{I}$. 
and (110), respectively. No peaks due to crystalline $\mathrm{MgO}$ or any other crystalline impurity phases were discerned. After calcination at $773 \mathrm{~K}$, the structure was that of a mixed oxide of the $\mathrm{Mg}-\mathrm{Al}$ type. Similarly, peaks belonging to crystalline $\mathrm{MgO}$ were not detected. XRD patterns of $\mathrm{Mg}-\mathrm{Al}-\mathrm{I}$ showed peak reflections at about $43^{\circ}$ and $62^{\circ}$, which corresponded to diffraction by planes (200) and (220) of the periclase in addition to $\mathrm{Al}_{2} \mathrm{O}_{3}$ (111), (100) and (110). These findings suggested that $\mathrm{MgO}$ could not be well dispersed on the surface of $\mathrm{Al}_{2} \mathrm{O}_{3}$ with 40 wt\% MgO content.

Structural properties of the samples are summarized in Table 1. The specific surface areas of $\mathrm{Mg}-\mathrm{Al}-\mathrm{C}, \mathrm{Mg}-\mathrm{Al}-\mathrm{H}$ and $\mathrm{Mg}-\mathrm{Al}-\mathrm{I}$ samples were 166,166 and $210 \mathrm{~m}^{2} \mathrm{~g}^{-1}$, respectively. $\mathrm{Mg}-\mathrm{Al}-\mathrm{C}$ and $\mathrm{Mg}-\mathrm{Al}-\mathrm{H}$ catalysts prepared by precipitation methods exhibited the same surface area. However, the $\mathrm{Mg}-\mathrm{Al}-\mathrm{I}$ sample preserved many more properties of the carrier with relatively high specific area. The average pore size pointed to mesoporous catalysts and increased successively from $\mathrm{Mg}-\mathrm{Al}-$ C, $\mathrm{Mg}-\mathrm{Al}-\mathrm{H}$ to $\mathrm{Mg}-\mathrm{Al}-\mathrm{I}$.

SEM images of the samples are shown in Fig. 2. It $\mathrm{Mg}-\mathrm{Al}-\mathrm{C}$ catalysts exhibited a lamella shape and $\mathrm{Mg}-\mathrm{Al}-\mathrm{H}$ samples presented a block-type shape. $\mathrm{Mg}$-Al-I samples presented a more "spongey" morphology. These data were in agreement with surface-area measurements because $\mathrm{Mg}$-Al-I presented a relatively high Brunauer-Emmett-Teller (BET) surface.

SEM with energy-dispersive X-ray analyses were used to analyze the chemical compositions and key components of the catalysts. Fig. 3(a-c) show SEM images at a scale of $20 \mu \mathrm{m}$. In accordance with the SEM images (a)-Mg, (a)-Al, (b)-Mg, (b)-Al,
(c)-Mg and (c)-Al, two discrete phases of $\mathrm{Mg}$ and $\mathrm{Al}$ were obtained. These findings suggested that $\mathrm{MgO}$ and $\mathrm{Al}_{2} \mathrm{O}_{3}$ were distributed uniformly in all the catalysts prepared by coprecipitation, HTLcs and impregnation.

TEM images of the samples are shown in Fig. 4. Samples of $\mathrm{Mg}-\mathrm{Al}-\mathrm{C}$ and $\mathrm{Mg}-\mathrm{Al}-\mathrm{H}$ showed a dense particle distribution. However, Mg-Al-I catalysts were distributed loosely. Similarly, TEM images of the samples were also in agreement with surface-area measurements.

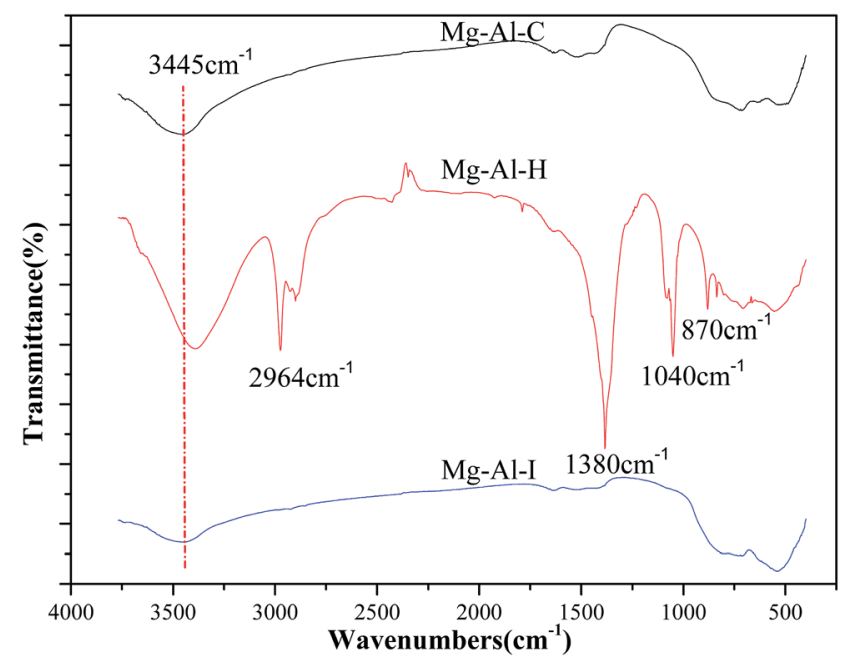

Fig. 5 FTIR spectra of catalyst samples.
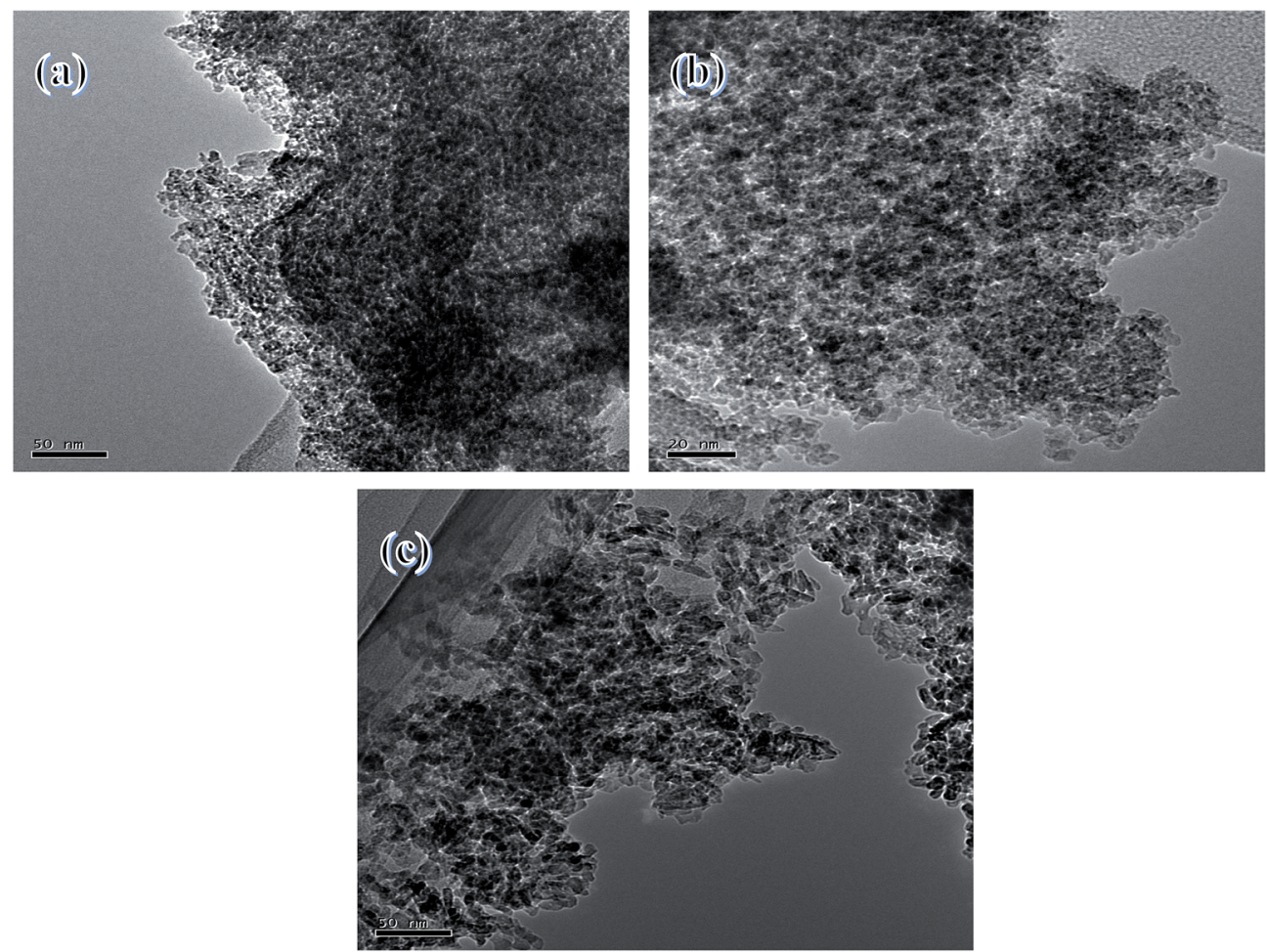

Fig. 4 TEM images of (a) $\mathrm{Mg}-\mathrm{Al}-\mathrm{C}$, (b) $\mathrm{Mg}-\mathrm{Al}-\mathrm{H}$ and (c) $\mathrm{Mg}-\mathrm{Al}-\mathrm{I}$. 
FTIR spectra showed a shared absorption band around 3445 $\mathrm{cm}^{-1}$ that was attributed to $\mathrm{OH}$ stretching vibrations (Fig. 5). Bands at $1040 \mathrm{~cm}^{-1}$ and $2964 \mathrm{~cm}^{-1}$ were due to a C-H symmetric stretching vibration. The band at $1380 \mathrm{~cm}^{-1}$ was attributed to $\mathrm{CO}^{3}-\mathrm{OH}^{28}$ These findings illustrated the many types of groups on the surface of the Mg-Al-H sample, which determined different properties compared with the other samples.

Acidic properties of $\mathrm{Mg}-\mathrm{Al}-\mathrm{C}, \mathrm{Mg}-\mathrm{Al}-\mathrm{H}$ and $\mathrm{Mg}-\mathrm{Al}-\mathrm{I}$ catalysts were investigated by $\mathrm{NH}_{3}$-TPD. The results are presented in Fig. 6(a) and the relative contents obtained by integration of the peak areas are given in Table 2. $\mathrm{NH}_{3}$-TPD profiles on all samples showed two intense peaks at around $423 \mathrm{~K}$ and $923 \mathrm{~K}$, which showed sites of weak and strong acids, respectively. The amount of $\mathrm{NH}_{3}$ desorbed on sites of weak and strong acids of $\mathrm{Mg}-\mathrm{Al}-\mathrm{C}$ was much higher than that on the other two samples.

Basic properties of the catalysts were studied by $\mathrm{CO}_{2}$-TPD (Fig. 6(b)). Two peaks of all three samples appear at around 423 $\mathrm{K}$ and $923 \mathrm{~K}$, respectively. The peak at the low temperature corresponded to sites of weak bases and the high temperature

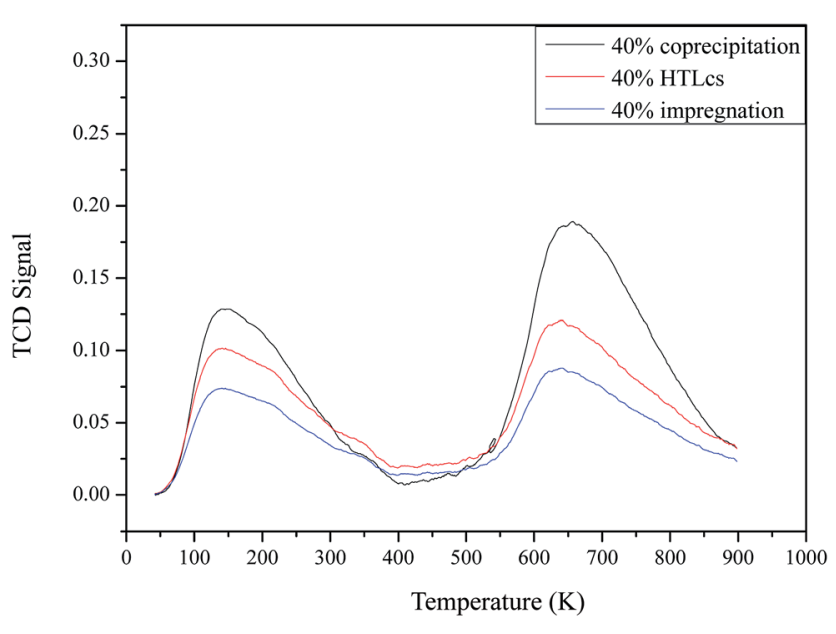

(a)

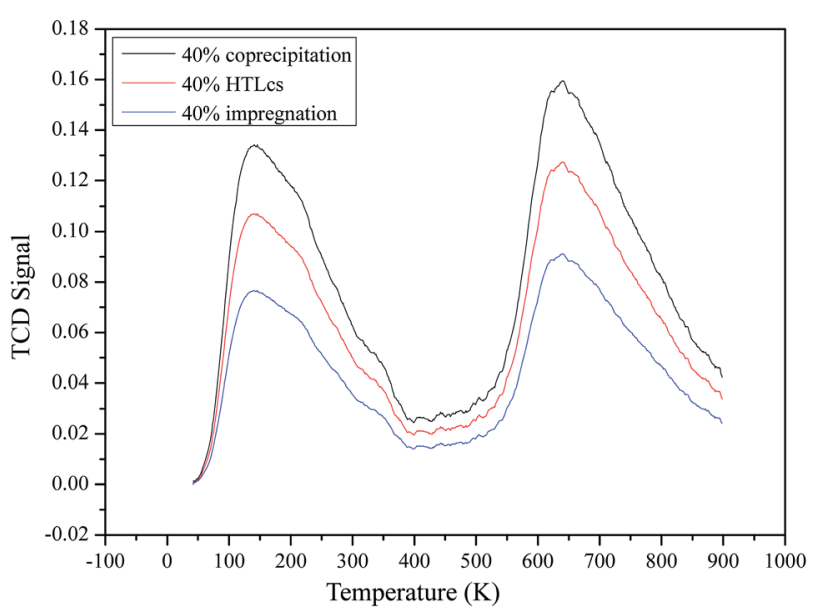

(b)

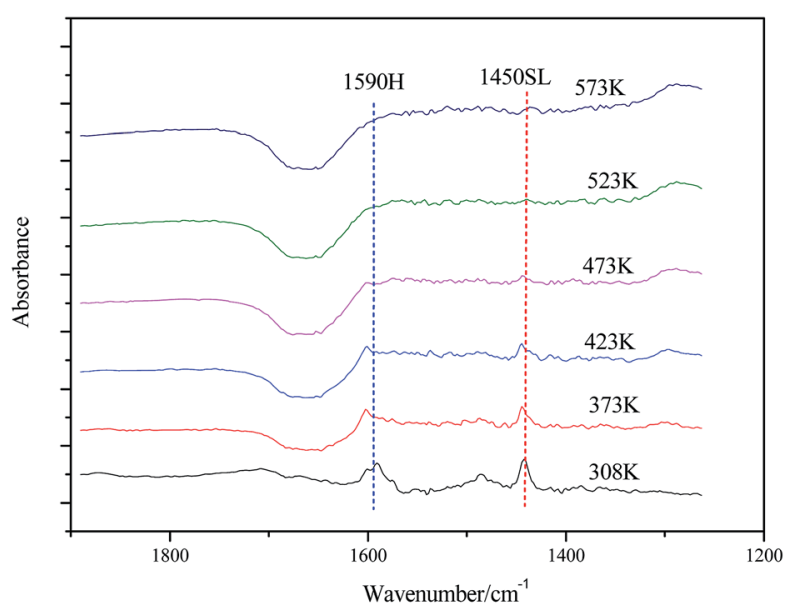

(a)

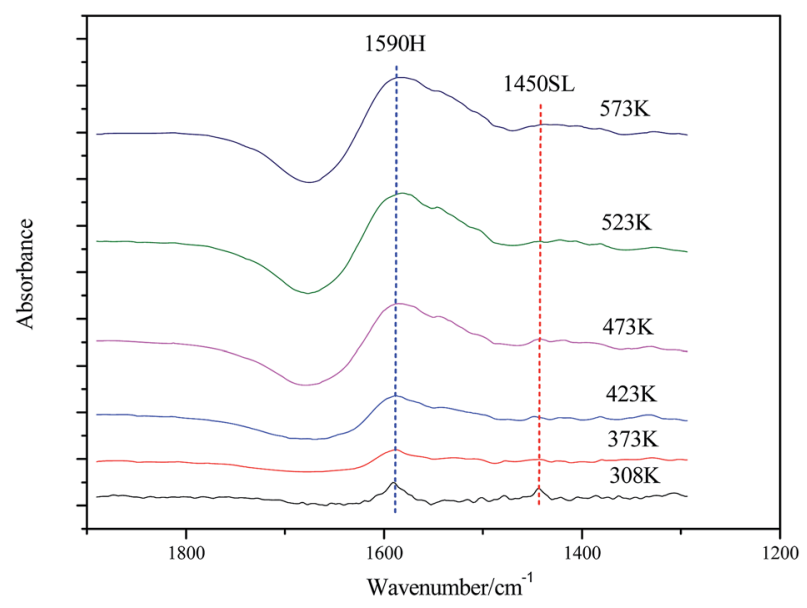

(b)

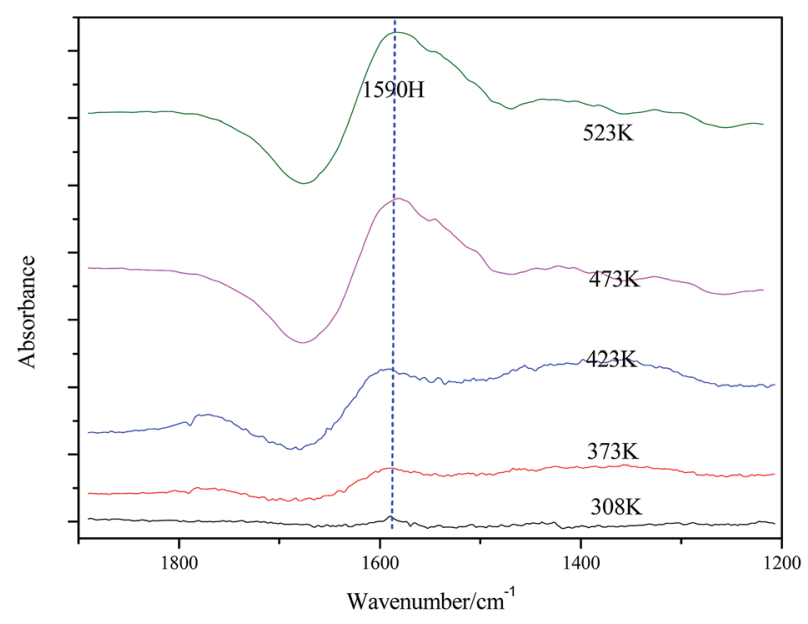

(c)

Fig. 7 FTIR spectra of (a) $\mathrm{Mg}-\mathrm{Al}-\mathrm{C}$, (b) $\mathrm{Mg}-\mathrm{Al}-\mathrm{H}$ and (c) $\mathrm{Mg}-\mathrm{Al}-\mathrm{I}$ after pyridine adsorption.

Fig. 6 TPD profiles on $\mathrm{Mg}-\mathrm{Al}$ catalysts (a) $\mathrm{NH}_{3}-\mathrm{TPD}$ and (b) $\mathrm{CO}_{2}-\mathrm{TPD}$. 
Table 2 Acidic and basic properties of catalysts

\begin{tabular}{llllllr}
\hline Preparation method & $\mathrm{WAS}^{a}\left(\mathrm{mmol} \mathrm{g}^{-1}\right)$ & $\mathrm{SAS}^{a}\left(\mathrm{mmol} \mathrm{g}^{-1}\right)$ & $\mathrm{TAS}^{b}\left(\mathrm{mmol} \mathrm{g}^{-1}\right)$ & $\mathrm{WBS}^{c}\left(\mathrm{mmol} \mathrm{g}^{-1}\right)$ & $\mathrm{SBS}^{c}\left(\mathrm{mmol} \mathrm{g}^{-1}\right)$ & $\mathrm{TBS}^{d}\left(\mathrm{mmol} \mathrm{g}^{-1}\right)$ \\
\hline Co-precipitation & 5.69 & 7.42 & 13.11 & 4.93 & 6.09 & 11.02 \\
HTLcs & 3.92 & 4.19 & 8.11 & 4.27 & 4.67 & 8.94 \\
Impregnation & 2.34 & 2.15 & 4.49 & 2.28 & 2.38 & 4.66
\end{tabular}

${ }^{a}$ Contents of weak acid sites (WAS) and strong acid sites (SAS) obtained by integration of the calibrated peak areas. ${ }^{b}$ Total contents of acid sites (TAS). ${ }^{c}$ Contents of weak basic sites (WBS) and strong basic sites (SBS) obtained by integration of the calibrated peak areas. ${ }^{d}$ Total contents of basic sites (TBS). The nature of the acidic sites was explored by infrared spectroscopy of the adsorbed pyridine (Fig. 7). For Mg-Al-C and Mg-Al-I samples, two main bands observed at $1590 \mathrm{~cm}^{-1}$ and $1450 \mathrm{~cm}^{-1}$ are were to $\mathrm{H}$-bonded pyridine and pyridine adsorbed on sites of a Lewis acid, respectively. Such peaks were not observed in $\mathrm{Mg}-\mathrm{Al}-\mathrm{H}$ samples except for the $\mathrm{H}$-bonded pyridine peaks $\left(1590 \mathrm{~cm}^{-1}\right)$. However, the band at $1450 \mathrm{~cm}^{-1}$ corresponding to a protonated pyridine was not detected in any of the samples studied. These results suggest that $\mathrm{Mg}-\mathrm{Al}-\mathrm{C}$ and $\mathrm{Mg}-\mathrm{Al}-\mathrm{I}$ samples had sites of a Lewis acid and that there were no sites of a Brönsted acid in any of the samples.

peak was attributed to sites of strong bases. The $\mathrm{Mg}-\mathrm{Al}-\mathrm{C}$ sample had relatively more sites of weak bases and there were more sites of strong bases on the surface of the $\mathrm{Mg}-\mathrm{Al}-\mathrm{H}$ sample, as shown by a typical sodium peak in the XRD patterns.
In summary, the investigation into the acid-base properties of $\mathrm{Mg}-\mathrm{Al}-\mathrm{C}, \mathrm{Mg}-\mathrm{Al}-\mathrm{H}$ and $\mathrm{Mg}-\mathrm{Al}-\mathrm{I}$ samples suggested that $\mathrm{Mg}-$ $\mathrm{Al}-\mathrm{C}$ catalysts contained a higher number of sites for weak acids and weak bases than for the other samples.

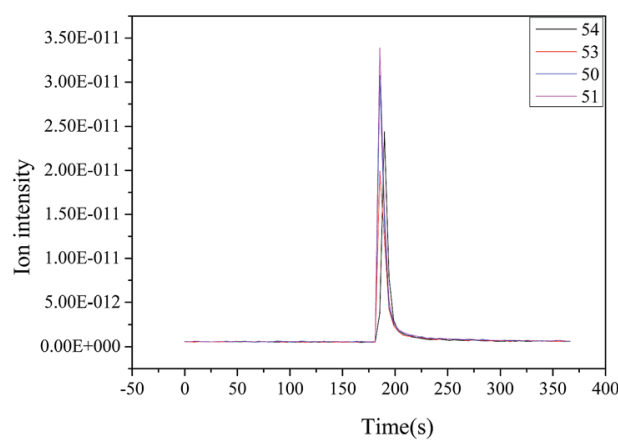

(a)

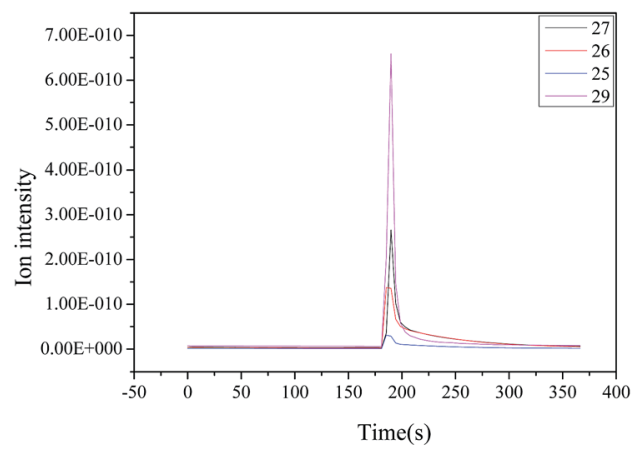

(c)

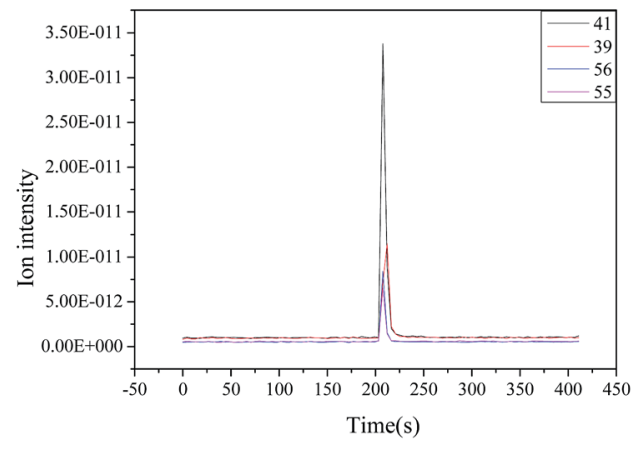

(e)

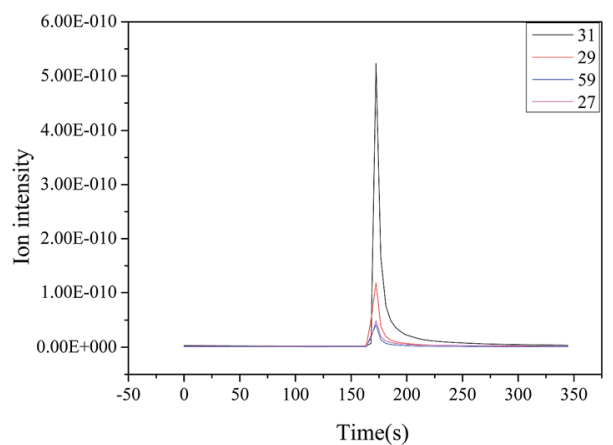

(b)

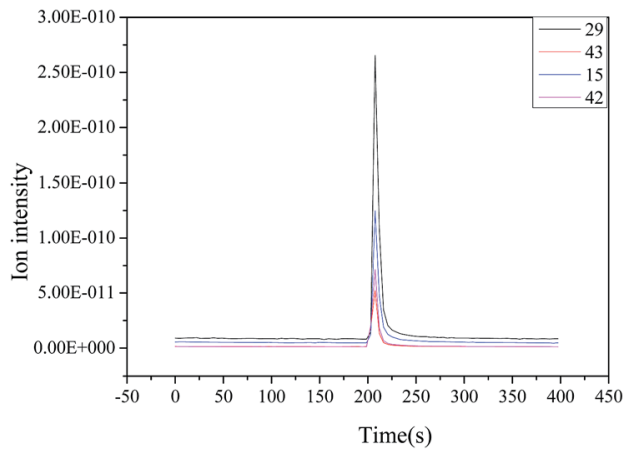

(d)

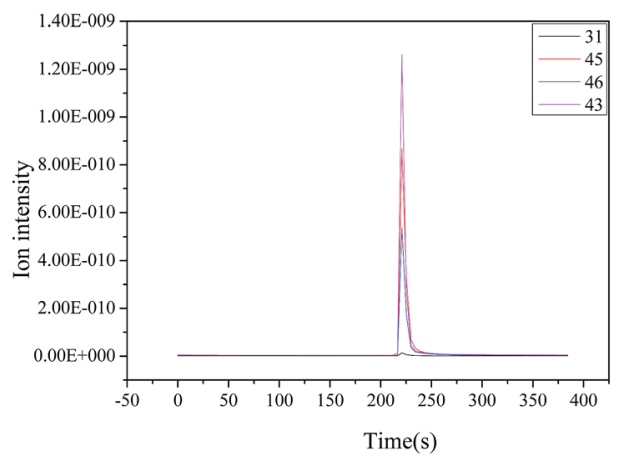

(f)

Fig. 8 Products of the ethanol reaction on Mg-Al-C catalyst (a) BD, (b) ethylene, (c) ether, (d) acetaldehyde, (e) 1-butene and (f) 1-butanol. 
Table 3 Selectivity of the products of ethanol transformation on $\mathrm{Mg}$-Al catalysts

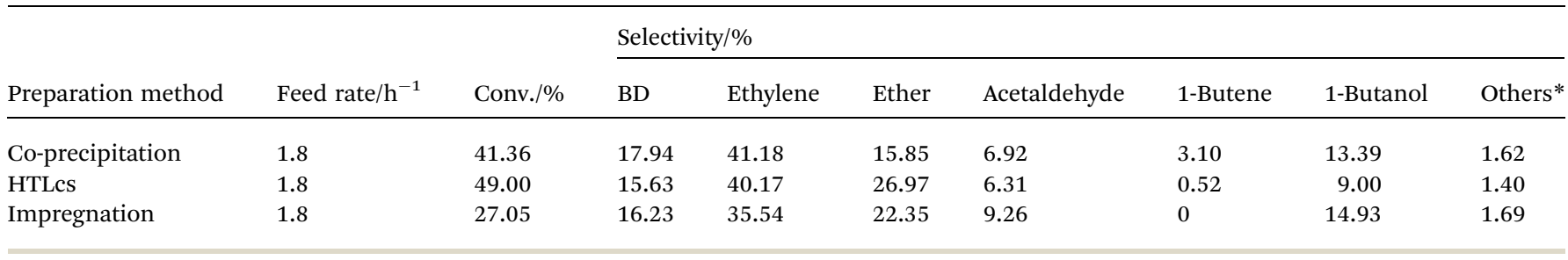

\subsection{Catalytic test for 1,3-butadiene production from ethanol}

To understand the process of ethanol conversion to $\mathrm{BD}$ more deeply, the ethanol-impulse response was carried out in the evaluated parameters of the $\mathrm{Mg}-\mathrm{Al}$ catalyst using $\mathrm{Mg}-\mathrm{Al}-\mathrm{C}$ as an example. The product distributions are shown in Fig. 8. The products of the ethanol reaction on the $\mathrm{Mg}-\mathrm{Al}-\mathrm{C}$ catalyst were $\mathrm{BD}$, ethylene, ether, acetaldehyde, 1-butene and 1-butanol. Then, we could speculate on the process of ethanol on the $\mathrm{Mg}$ $\mathrm{Al}-\mathrm{C}$ catalyst. That is: ethylene and ether were formed from ethanol through dehydration; ethanol was dehydrogenated to acetaldehyde; acetaldehyde underwent an aldol condensation with ethanol to form an acetaldol; through dehydration and a MPV-type reduction to generate $\mathrm{BD}, 1$-butene arose from the growth of carbon chains and dehydrogenation. Butanol was obtained from crotyl alcohol-selective hydrogenation of the unsaturated carbon-carbon double bonds.

The ethanol conversions and distribution of products are listed in Table 3. Conversions of ethanol on $\mathrm{Mg}-\mathrm{Al}-\mathrm{C}$ and $\mathrm{Mg}$ $\mathrm{Al}-\mathrm{H}$ were $41.36 \%$ and $49.00 \%$, respectively. Ethanol transformation on $\mathrm{Mg}-\mathrm{Al}-\mathrm{I}$ was relatively poor $(27.05 \%)$ and was probably due to fewer active sites on the surface of $\mathrm{Mg}-\mathrm{Al}-\mathrm{I}$ catalysts.

The reaction products were mainly $\mathrm{BD}$, ethylene, ether, acetaldehyde, 1-butene and 1-butanol. The products dehydrated from ethanol on sites of strong acids (e.g., ethylene) took up a large proportion. Acetaldehyde dehydrogenated from ethanol on sites of strong bases was also produced. Selectivity of BD on $\mathrm{Mg}-\mathrm{Al}-\mathrm{C}, \mathrm{Mg}-\mathrm{Al}-\mathrm{H}$ and $\mathrm{Mg}-\mathrm{Al}-\mathrm{I}$ catalysts were $17.94 \%, 15.63 \%$ and $16.23 \%$, respectively, which suggested fewer acidic-basic sites suitable for BD formation from ethanol on the surface of $\mathrm{Mg}-\mathrm{Al}$ catalysts.

Based on the acid-base properties of $\mathrm{Mg}-\mathrm{Al}-\mathrm{C}, \mathrm{Mg}-\mathrm{Al}-\mathrm{H}$ and Mg-Al-I samples, we could draw three main conclusions. First, the sites of strong based and strong acids in $\mathrm{Mg}-\mathrm{Al}$ catalytic systems possibly exerted negative effects. Second, the ethanol reactions of dehydration and dehydrogenation were carried out mainly on sites of strong acids and strong bases. Finally, to obtain higher BD selectivity, modifiers used to adjust the acidbase balance must be adopted in $\mathrm{Mg}-\mathrm{Al}$ catalysts.

\section{Conclusions}

Production of BD and other bulk chemicals from ethanol over $\mathrm{Mg}-\mathrm{Al}$ catalysts using different preparation methods was investigated. All types of catalysts tested obeyed the same mechanistic pathways and showed an identical set of products.
The reaction products were mainly $\mathrm{BD}$, ethylene, ether, acetaldehyde, 1-butene and 1-butanol.

The characterization and analyses of samples suggested that preparation methods had an impact on the surface structure and chemical nature of the catalysts. $\mathrm{Mg}-\mathrm{Al}-\mathrm{C}$ and $\mathrm{Mg}-\mathrm{Al}-\mathrm{H}$ catalysts prepared by precipitation methods exhibited almost identical surface areas. However, the $\mathrm{Mg}-\mathrm{Al}-\mathrm{I}$ sample retained many more properties of the carrier with a relatively high specific area. $\mathrm{Mg}-\mathrm{Al}-\mathrm{C}$ samples had relatively more sites of weak acids and weak bases than the other samples. Moreover, $\mathrm{Mg}-\mathrm{Al}-$ $\mathrm{C}$ and $\mathrm{Mg}-\mathrm{Al}-\mathrm{I}$ samples had sites for a Lewis acid but there were no sites for a Brönsted acid in any samples.

Sites for moderately strong acids and bases could enable formation of BD. Dehydration and dehydrogenation of ethanol to ethylene was carried out mainly on the sites for strong acids and strong bases. To obtain higher product selectivity, the ratios of $\mathrm{MgO}$ and $\mathrm{Al}_{2} \mathrm{O}_{3}$ must be examined and modifiers used to adjust the acid-base balance must be adopted in $\mathrm{Mg}-\mathrm{Al}$ catalysts.

\section{References}

1 R. Bhatt, D. Shah, K. C. Patel and U. Trivedi, Biotechnol. Bioeng., 2008, 99, 4615-4620.

2 E. V. Makshina, M. Dusselier, W. Janssens, J. Degrève, P. A. Jacobs and B. F. Sels, Chem. Soc. Rev., 2014, 43, 79177953.

3 W. C. White, Chem. Boil. Interact., 2007, 166, 10-14.

4 Y. Sun and J. Y. Cheng, Biotechnol. Bioeng., 2002, 83, 1-11.

5 J. O. Alves, C. Zhuo, Y. A. Levendis and J. A. Tenório, Appl. Catal., B, 2011, 106, 433-444.

6 R. O. de Souza, L. S. Miranda and R. Luque, Green Chem., 2014, 16, 2386-2405.

7 K. D. Maher and D. C. Bressler, Biotechnol. Bioeng., 2007, 98, 2351-2368.

8 K. A. Gray, L. S. Zhao and M. Emptage, Current Opinion in Chemical Biology, 2006, 10, 141-146.

9 P. Alvira, E. Tomas-Pejo, M. Ballesteros and M. Negro, Bioresour. Technol., 2010, 101, 4851-4861.

10 B. Hahn-Hagerdal, M. Galbe, M. F. Gorwa-Grauslund, G. Liden and G. Zacchi, Trends Biotechnol., 2006, 24, 549556.

11 J. Ostromislenskiy, J. Russ. Phys.-Chem. Soc., 1915, 47, 14721506.

12 S. V. Lebedev and A. O. Yakubchik, J. Chem. Soc., 1929, 220225. 
13 W. M. Quattlebaum, W. J. Toussaint and J. T. Dunn, J. Am. Chem. Soc., 1947, 69, 593-599.

14 S. K. Bhattacharyya and N. D. Ganguly, J. Appl. Chem., 1962, 12, 105-110.

15 M. Gao, M. Zhang and Y. Li, RSC Adv., 2017, 7(20), 1192911937.

16 S. Kvisle, A. Aguero and R. P. A. Sneeden, Appl. Catal., 1988, 43, 117.

17 V. V. Ordomsky, V. L. Sushkevich and I. I. Ivanova, J. Mol. Catal. A: Chem., 2010, 333, 85-93.

18 V. L. Sushkevich, I. I. Ivanova, V. V. Ordomsky and E. Taarning, ChemSusChem, 2014, 7, 2527-2536.

19 H.-J. Chae, T.-W. Kim, Y.-K. Moon, H.-K. Kim, K.-E. Jeong, C.-U. Kim and S. Y. Jeong, Appl. Catal., B, 2014, 150, 596-604.

20 E. V. Makshina, W. Janssens, B. F. Sels and P. A. Jacobs, Catal. Today, 2012, 198, 338-344.
21 M. D. Jones, C. G. Keir, C. D. Iulio, R. A. M. Robertson, C. V. Williams and D. C. Apperley, Catal. Sci. Technol., 2011, 1, 267-272.

22 M. H. Zhang, M. X. Gao, J. Y. Chen and Y. Z. Yu, RSC Adv., 2015, 5, 25959-25966.

23 M. X. Gao, Z. Z. Liu, M. H. Zhang and L. Tong, Catal. Lett., 2014, 144, 2071-2079.

24 J. I. Di Cosimo, V. K. Diez, M. Xu, E. Iglesia and C. R. Apesteguia, J. Catal., 1998, 178, 499-510.

25 K. K. Rao, M. Gravelle, J. S. Valente and F. Figueras, J. Catal., 1998, 173, 115-121.

26 L. Hora, V. Kelbichová, O. Kikhtyanin, O. Bortnovskiy and D. Kubička, Catal. Today, 2014, 223, 138-147.

27 M. León, E. Díaz and S. Ordóñez, Catal. Today, 2014, 164, 436-442.

28 J. T. Kloprogge, D. Wharton, L. Hickey and R. L. Frost, Am. Mineral., 2007, 87(5-6), 623-629. 